\title{
Evaluation of the Technology Integration Process in the Turkish Education System
}

\author{
Nuray Parlak Yilmaz \\ Uludag University, Turkey
}

\begin{abstract}
Twenty-six years have passed since computers entered the Turkish Education System. Studies regarding the evaluation of the integration process reveal that the technology use has not yet been reflected into classroom activities sufficiently. This article aims to evaluate studies conducted from the beginning of the process to determine problems with regard to the integration process, especially by focusing on the elementary education. The article carefully examined the relevant literature, short-term action plans, circulars, regulations, project documents, and research studies. It appears that all the investments and projects carried out so far regarding the generalization of the use of ICT in education have remained mostly at macro level. More concrete policies and practices taking all the dimensions into consideration were put into practice only in the last period of the technology integration process. There are still problems at present situation particularly in the dimensions of infrastructure, teacher education, instructional materials, and software. Micro-level studies, which are carried out at the level of individual school, should be supported. Then, there will be better chances to convert the results of studies into policies for effective reform.
\end{abstract}

Keywords: Technology integration; Educational reform; K-8; Turkish education system

\section{Introduction}

As stated clearly in the Information Society Strategy Report, "There are serious opportunities in the mid-run before Turkey to be able to turn into an information society because of its demographic structure" (DPT, 2006b). In order to make use of this opportunity, it is necessary that the country should educate this young population in accordance with the requirements of the age. Within this scope, serious work has been carried out for twenty-six years to make the use of new and gradually developing information and communication technologies in Turkey. According to the basic understanding of educational technology, the success of investments made in technology in the field of education depends on effective and efficient use of these technologies at the school level. Otherwise, the use becomes controversial. Hoffman (2001) indicates that the success of technology at the school level is related to the ability to integrate technology into the classroom.

The results of pertinent studies aiming to determine the present condition of the Turkish Education System indicate that there has been an increase in the use of these technologies by teachers, as in other countries; however, due to the problems originating from the factors affecting the integration process, the reflection of technology use in classroom activities has not yet reached the ideal level under integration. In these studies, it was found that teachers use the technologies more in administrative and personal work but less in teaching (Aşkar \& 
Koçak-Usluel, 2002a; 2002b; 2003; Çağıltay, Çakıroğlu, Çağıltay, \& Çakıroğlu, 2001; Demiraslan \& Koçak- Usluel, 2005; Goktas, Yıldırım, \& Yıldırım, 2008; Koçak-Usluel \& Aşkar, 2006; KoçakUsluel, Mumcu, \& Demiraslan, 2007). However, in a study by Koçak-Usluel, Mumcu and Demiraslan (2007), findings were obtained with regard to the variety of uses of the ICT in learning-teaching processes (though use remained at low rates). Additionally, in the study by Demiraslan and Koçak-Usluel (2005), findings were obtained supporting this result.

However, it must be kept in mind that the integration process is both a quite comprehensive and a complicated one. For this simple reason, it becomes inevitable to come across various obstacles during the process. Within this scope, starting from the works carried out as an approach from the beginning of the process in order to determine the point reached in the technology integration process at elementary education level and reasons of the problems might enable us to evaluate the process with a more integrated point of view. Starting from this point of view, the present article aims to evaluate the studies carried out as of the beginning of the process, especially by focusing on the elementary education level in order to determine the problems in the technology integration process of our education system.

\section{Method}

In this study, survey type research model was used. In the study carried out based on the literature, short-term action plans and the evaluation reports about these plans, circulars, regulations, project documents, and research studies made on the subject matter were referred.

The technology integration process taken under evaluation was limited to the elementary education level. In this study, the emerging developments in the integration process are examined in three periods considered to characterize the major stages of the process. The first stage is seen as having begun in the early 1980s and ended in the year 1997, in which basic education was expanded to eight years; the period beginning with the acceptance of the 1997 Basic Education Law expanding basic education to eight years as a requirement of the vision for the 21st century of Turkey is called the second period; and the process beginning with the '2003 e-Transformation Turkey Project,' which is still continuing today, is the third period. The evaluation of these three periods was discussed under separate headings in this study.

\section{First Period}

The first campaign began in 1984 at the secondary education level; later the scope was expanded through the inclusion of primary education. Although computers were initially used for computer education, they started to be used for computer-assisted education (CAE) with the 1988 Computer-Assisted Education Project (CAEP).

Another project was the National Education Development Project (NEDP), which started in 1992 with the financial support by the World Bank and was completed in 1997 (MEB EĞiTEK, 2002). Within the scope of this project aiming to increase the quality of primary and secondary education (MEB, 1999), two other pilot projects directed toward the use of computers in education were carried out (the 53 Computer Try-out School Project and 182 Computer Laboratory School Project). In these projects the aim was to carry out research and development, predominantly to develop software for CAE (MEB, 1991). 
Like many countries, Turkey espouses a training approach aimed at having teachers who have been trained through in-service training and then teach other teachers at their own schools. The teachers who are responsible for training other teachers are called formatter teachers.

Formatter teachership, together with computer teachership, was first considered within the scope of NEDP. With a directive put into practice in 1993, the criteria to be taken into account in selecting teachers for these two fields of teachership and the duties of the formatter teachers were defined (MEB, 2006a). This directive is still in effect, although some articles have been modified.

Within the scope of NEDP, in the year 1996, the training of 256 new formatter teachers was completed; moreover, the 314 formatter teachers were retrained (MEB EĞiTEK, 2002). Following cooperation with universities between the years 1991 and 2002, a total of 3,180 computer formatter teachers were trained (MEB EĞiTEK, 2002)

Incorporating computers into the Turkish Education System led to arrangements not only at the school level but also at the level of the Ministry of National Education. General Directorate of Computer Services and Education (GDCSE) was established in 1992 at the level of the MNE to carry out computer-assisted education-oriented work. The MNE in that period, within the scope of NEDP, carried out work to make the administrational services it provided more effective at using information technologies (MEB EĞiTEK, 2008). For this purpose, it was planned to transport the activities of various units of the ministry into an electronic environment by setting up the system that was then called the Integrated Administrational Information System of the Ministry of National Education (MNESIS) (MEB EĞiTEK, 2002). This system, which was eventually named the Information System of the Ministry of National Education (MNEBiS), was made accessible on the Internet by configuring a web-based module in 2007 (Uyanıker, 2007).

However, work related to the CAE, contrary to what had been planned, was continued in such a way that it included the dimensions of hardware and teacher training and disregarded the dimension of integrating implementation with the curricula and giving primary importance to the dimension of software.

Because the development of educational software making use of the country's own means and in its own language was adopted as the basic principle throughout Turkey, many educational software development projects were carried out by different firms in that period. However, in the evaluations made afterwards, some of this software was not found to have the expected qualities and be sufficiently original (MEB, 1991). Another of the critiques made concerning the matter is related to the methods and criteria followed in software development and selection (Şimşek, 1998). Moreover, this idea of generalizing the implementations of CAE within the general framework of a master plan that was prepared under the umbrella of pilot project implemented could not be put into practice (MEB, 1991).

\section{Second Period}

A new period began in Turkey with the Catching the Era in Education 2000 Project. With this project, a series of developments took place that were directed especially at the primary education system and that at the same time aimed to prepare the system for the twenty-first 
century. Within this scope, in the Turkish Education System, a legal regulation was introduced in 1997 primarily concerning the expansion of primary education to eight years. To implement the new basic education strategy prepared within the framework of the Law numbered 4036, the Basic Education Project (BEP), financially supported by the World Bank, was put into effect in 1998 (Eurydice, 2007).

In this characteristic period underpinning the preparation for the new century, information technologies were used in order to actualize transformation in the field of education. For this reason, work in this period was directed toward generalizing the use of information technologies, primarily in primary education toward integrating them into the system (MEB, 2002; MEB, 2004).

The first program put into effect with the BEP 1st Phase Project was the actualization of computer education through a newly prepared computer course program at the basic education level (MEB EĞiTEK, 2003a). In this way, the course of computer sciences began to be taught as an elective starting in the fourth grade in primary education in 1998.

Following this development, to train teachers who were to teach computer science at the primary school level, Departments of Computer Education and Instructional Technology began to be opened within the education faculties in 1997. The number of relevant departments had increased to 29 by the 2006- 2007 academic year. The number of students enrolled in the sole department had increased to 1,255 by 2006 . Today, most of the computer teachers employed by the MNE graduated from these departments. The number of these teachers was 8,785 by 2006 (YÖK, 2007).

Another development during this period was the inclusion of a compulsory computer science course in the programs at all teaching departments within the framework of restructuring education faculties, as well as the start of the process of having teachers acquire computer literacy skills before service.

Within the scope of the BEP, it was aimed at using ICT in school subjects other than computer science courses starting in the fourth grade in primary schools (MEB, 2004). Meanwhile, the computer laboratories set up in the first period were replaced by 3,188 Information Technology (IT) classrooms. Moreover, with the internet connections provided in the IT classrooms, the goal was to use the Internet for teaching purposes (DPT, 2004; MEB APK, 2002; MEB EĞiTEK, 2003).

Kılıç and Özdemir (2006) conducted a study of the distribution of IT classrooms set up during the first phase of the BEP and found that because the MNE had not taken into account the number of students in the various areas during the distribution of hardware, and it set up fewer IT classrooms in the areas where the number of students is high and more IT classrooms in the areas where the number of students is low. They stated that due to this policy, the duration of student-computer interaction did not exceed one hour per week, and for this reason, it was not possible to use these classrooms for both computer education and computer-assisted instruction as originally aimed.

In the second period, the MNE established EDUTECH in 1998 to be able to create an education system compatible with the developing technology and put into effect the new education models and methods required by the era (MEB EĞiTEK, 2002). At present, all implementation 
regarding the integration of ICT into the Turkish Education System is carried out by the EDUTECH in the name of the MNE.

Despite these developments, the goal of the integration of ICT into teaching processes could not be achieved by the BEP, as in the first period in which the generalized implementation of CAE was attempted. Because the IT classrooms were used mostly for computer education, use for educational purposes could not be generalized (Taslak Rapor, 2004). Furthermore, the course content and course loads of the primary school programs applied in that period were not suitable for integrating ICT into education (Taslak Rapor, 2004). The same matter was also mentioned in the MNE ICT Policy Draft Document, and the necessity of a teaching program modification was highlighted (MEB, 2003).

\section{Third Period}

The most important characteristic of the third period, including ICT implementation in the Turkish Education System after 2000, was the process of transformation into an information society that also occurred in the same period in Turkey. For this reason, in evaluating the third period's projects, it is necessary to track those carried out within the framework of the transformation into an information society as well.

From the 2000's on, worldwide, within the scope of the transformation into an information society, a series of initiatives was launched [World Information Society Summit (2003), (2005) and EU Initiatives] (DPT, 2005b). The work done in Turkey increased as well in tandem with the EU membership process starting in 2001. Turkey became a party to the e-Europe ${ }^{+}$initiative designed for the EU member candidate countries in 2001, and in 2003, it prepared its own eTransformation Turkey Project and put it into effect (DPT, 2006b; e-Avrupa+ Eylem Planı, 2001).

Within the scope of this project, two Short-Term Action Plans (STAP) were prepared, one covered the 2003-2004 period and the other one covered the 2004-2005 period. In the first of these (2003-2004), legal and technical infrastructure was given priority, while in the second period, extending attempts to reflect the actions into daily life were given priority (DPT, 2006a). Lastly, with the Information Society Strategy and an Action Plan prepared in 2006, medium-term and long-term strategies and targets on the part of Turkey covering the 20062010 period were identified. This plan is important in that it indicates the road map that Turkey will follow until 2010 in the process of transformation into an information society (DPT, 2006b).

The work started in the field of education within the scope of preparation to become an information society in the late 1990s took a new shape from this point onward in terms of content and approaches with the action plans prepared within the scope of the eTransformation Turkey Project. With the contributions that the project provided, it has become possible to present an integrated viewpoint and more concrete policies and targets concerning the extending of the ICT in the field of education as of this period (DPT, 2006b).

It appears that every step runs parallel to the e-Transformation Turkey Project with both the project plans that the MNE made for projects to be started after 2000 within the framework of 
the policy of integrating ICT into education (MEB EĞiTEK, 2003a) and the steps it has actually taken.

The projects that have been carried out in the third period can be discussed under two headings according to their type of financial resources. The first of these includes projects financed by foreign resources and put into practice under the responsibility of the MNE; other one includes the projects financially supported by the MNE and carried out by EDUTECH. One of the two important projects financed by foreign resources is the BEP-Phase II Project, which was implemented with the financial support by the World Bank in 2002; the other one is Basic Education Support Project.

The effort to set up IT classrooms was continued within the scope of BEP- Phase II Project. In Turkey, projects to secure the support of the private sector were carried out as well. This projects are the Computer Based Education Support Project and the 100\% Support to Education Campaign. Some of these projects are still in effect.

The number of the IT classrooms set up with the support of domestic and foreign resources and various private organizations was 29,264 by 2008 (MEB EĞiTEK, 2008a). According to the last statistics, at the primary education level, the number of students per computer was 45; at the secondary education level, it was 37; and in the fields of vocational and technical education, it was 11 (Aktürk, 2006).

The goal of setting up IT classrooms in primary schools included in the first STAP has not been easy to reach in the short run for a country whose population is composed mostly of young people. For this reason, this goal was included in all the action plans prepared. The project investments started in 2005 under the responsibility the MNE were planned to be concluded in 2009, and those carried out by the Ministry of Transport and Communication from 2006 until today were planned to be concluded in 2008 (DPT, 2008b).

Although the goal of setting up an IT classroom in every school at the primary education level has been achieved, the high number of students per classroom (DPT, 2008a) will continue to negatively affect the efficiency of the lessons taught in these classrooms (Deryakulu, 2005; DPT,2006b).

On the other hand, the new trend in the implementation of technology integration is the integration of technology into classrooms. Parallel to this development, the new goal set by the MNE is to provide a computer to every classroom at the primary education stage (BTHaber, 2008a). The increase in teachers' skills with ICT naturally encourages them to use these technologies in their classrooms. The need for computers as caused by this trend is being addressed using different resources at the school level (with support by school heads and students' parents).

The other problems with IT classrooms are the deficiencies in peripheral equipment and slow Internet connections (Akbaba-Altun, 2006). Moreover, because IT classrooms at schools are converted from old classrooms, there are problems in setting up laboratories (Akbaba-Altun, 2006; Deryakulu, 2005).

Regarding the infrastructure, as well as in providing schools with hardware and Internet connections, it is also important that technical support be provided so that present systems can continue to operate. In this respect, the repair and maintenance policies followed in the 
integration process are of great importance. The MNE provides service support through the firms from which it purchases hardware under the guarantee within the framework of the BEP. In all of the action plans carried out within the framework of the e-Transformation Turkey Project, it is emphasized that the IT classrooms should be open to public in order for them to be used effectively and efficiently. At the same time, the aim is to create resources for these classrooms. However, the desired goal could not be achieved. Among the reasons for this failure was hesitancy on the part of administrators and the insufficiency of the staff and allowance (DPT, 2004; DPT, 2006c).

Another dimension of the infrastructure work related to the integration processes includes the work done to provide IT classrooms with Internet connections. In the first STAP prepared in this direction, the campaign "Open a School to the World, Connect it to the Internet" was introduced. With this campaign, the goal was to connect schools to the Internet through the sponsorship of voluntary persons and organizations (DPT, 2004) in addition to public funds. Also, the MNE Internet Access Project (2003), aimed to provide the schools and institutions connected to the MNE and the IT classrooms present in schools with fast and continuous Internet connections. Within the scope of the project, ADSL connections in all the schools were completed (MEB, 2007b).

Another project put into effect in this period was the Basic Education Support Project (BESP). The BESP is a project financed by the European Commission to support the vision of the MNE about basic education and contribute to its developing and continuing work within the framework of the BEP (MEB, 2005). The work carried out within this project, at the same time, furthers the e-education goal of the e-Transformation Turkey Project and contributes to the transition of action items into implementation.

Some of the most important works carried out within the framework of the BESP is the development of primary school course programs. The new primary school course programs prepared in accordance with the constructivist approach were put into use starting with the $2005-2006$ school year. This work was carried out within the scope of program renewal, while the infrastructure work was carried out as part of the campaign to promote the use of the ICT in education, and these were evaluated as among the successful campaigns of the eTransformation Turkey Project mentioned in the report on the developments between the years 2003 and 2007 (DPT, 2007).

Because the program renewal work has been evaluated using an integrated viewpoint since the beginning (MEB TTKB, 2007), the Secondary Education Project was also begun to renew the teaching programs for the courses given at secondary education institutions (DPT, 2008c).

Among the renewed course programs is also the ICT Course program. In the new secondary education program, ICT skill is taken as one of the eight skills that students should acquire. The program at the primary school level was put into practice during the 2006-2007 school year. However deleting the fourth and fifth stages of the curriculum at the beginning of 2010-2011 academic term may cause some undesired results (is worrying). Besides, to assign just one hour per week for the course aiming to acquire some advanced level skills does not support the targets of the curriculum.

In addition to the BEP - Phase II Project and the BESP, work is also carried out within the scope of the projects supported by the MNE and carried out by EDUTECH that is directed to create the conditions for program development activities to be successfully put into practice. 
Within this framework, it is especially important to overcome the problem of training teachers to implement new programs. Teachers' lack of sufficient information about ICT integration and inadequacies in training meant to help individuals overcome these deficiencies form the most important obstacles to the use of these technologies for teaching purposes.

Teachers need support related to both computer literacy and integrating ICT into learningteaching processes if they are to be able to implement the new programs. For this reason, as it has been true throughout the process, the third period, has featured projects such as the Intel Teacher Training Project, the Microsoft Innovative Teachers Program and Information Technologies and the Formatter Teacher Program, that have aimed to train teachers through in-service programs in the direction of need.

Beginning with the introduction of computers into the education system in Turkey, many inservice training programs have been carried out to train teachers serving in the system. The contents of these programs were created within the scope of the integration of the ICT into the learning-teaching processes following the project carried out in collaboration with the Intel firm after 2003. There are research results revealing that teachers attending programs with integration contents use the ICT in their lessons at high rates (Mulkeen, 2003). Although the first year of the Intel Teacher Training Project carried out in our country with this aim was 2003 , the first year of implementation of the primary education teaching programs prepared with the new vision was 2005. Therefore, it is necessary to evaluate the new content of the inservice training program taking this into account.

In the third period, in addition to the training given to teachers regarding the use of the ICT in teaching processes, they were also made to acquire computer literacy through distance education within the framework of the Microsoft Cooperation in Education Program. Moreover, with the aim of encouraging teachers to use computers, a campaign was conducted by the MNE directed toward helping them own computers as well. Thanks to the campaign, evaluated as one of the successful campaigns of e-Transformation Turkey Project (DPT, 2007), 85,000 teachers took possession of laptop computers in that period (Aktürk, 2006).

Teachers' inability to integrate the ICTs into learning-teaching processes forms one of the most important obstacles in the use of these technologies at K-12 schools with the aim of teaching. The result of Yucel, Acun, Tarman, and Mete (2010) is notable in this respect. Yucel et al. (2010) found that ICT knowledge of teachers was a crucial variable in ICT integration. For this reason, it is critical to integrate the ICTs into formal pre-service teacher education. In addition to in-service teacher training sessions, it was decided to expand the study period for the computer science courses, which had been taught during only one semester, to two semesters; this arrangement was made with formal teacher education programs in 2006 (YÖK, 2006). Gulbahar (2008) reported in her research that teacher training programs fail to provide appropriate instructional technologies and computer facilities for both in and out of class activities. Goktas, Yıldırım, and Yıldırım, (2009) found that ICT resources and infrastructures in schools of teacher education are limited. These results are not enough in order to specify the current case in Turkey.

Another group of teachers serving within the framework of the integration of the ICT into learning-teaching processes are the computer formatter teachers. The contents of the training sessions given to this group of teachers, whose training has continued since the 1990s, have undergone modifications over time as well. (MEB EĞiTEK, 2007a). As a result of the increase in 
the number of IT classrooms, both formatter teachers trained through in-service training programs and computer science teachers educated in formal education programs started to be charged as formatter teachers in the primary schools by 2007 (MEB EĞiTEK, 2007c). Although this decision was expressed in circular 53 issued in 2001 (MEB EĞiTEK, 2001), the effective enforcement of this decision became possible only after that date.

In the study by Orhan and Akkoyunlu (2003) which aimed to find out the problems that these teachers have, the formatter teachers stated that they had problems with their personal benefits, that their authority and responsibilities were not clear enough, and that they both taught computer science lessons and served as formatter teachers at the same time, they had a course overload. The course load of these teachers was reduced to 10 hours a week with an arrangement made in 2008.

Both individual and institutional factors shaped by the differences in the structure and functioning of the schools play an important role in the adoption speed of the ICT. Institutional obstacles directly affect technology use in an institution by affecting teachers' knowledge, skills and attitude toward technology (Hew \& Brush, 2007; Hoffman, 2001). The findings from the research studies conducted in Turkey by Aşkar and Koçak-Usluel (2003) in three different schools with a two-year interval supported this result as well. Moreover, Demiraslan and Koçak-Usluel (2005), moving from the study they carried out, pointed to the importance of the support given by the school administration during the integration process.

In the related literature, school technology plans and leadership factors are included among the institutional factors creating obstacles during the integration process. When the matter is considered from the viewpoint of technology plans, it appears that the practice of technology plans is not widespread at the school level in Turkey but rather is limited to personal work (Gülbahar; 2007; Saban; 2007).

The findings obtained from the studies investigating the extent to which school heads with the responsibility for the integration process at the school level in Turkey can fulfill their roles (Akbaba-Altun, 2003; Akbaba-Altun, 2006; Akbaba-Altun \& Gürer, 2008; Cerit, 2007; Deryakulu, 2005; Deryakulu \& Olkun, 2007; Orhan \& Akkoyunlu, 2003) indicates that school heads struggle in this capacity. Şimşek (2009) states that "both the organizational structure of the Turkish education system and the training and appointment conditions of the school heads do not make possible the concept of "school leadership" in Turkey" (p. 11).

To be able to implement new education programs successfully, not only the need for trained teachers but also the need for quantitative education content and teaching materials should be met. In the third period, the most comprehensive work carried out by the MNE regarding the formation of quantitative education contents has been the Education Portal Prototype Formation Project. It was intended that the portal whose duty could not be limited to only providing teachers and students with quantitative content support would undertake a more comprehensive function, which was to contribute to the e-transformation in education (DPT; Eylül, 2004).

The content enrichment work of the portal, which was started to be broadcast temporarily by modeling following the configuration work, is still continuing today. One of the significant problems that appeared during the addition of Turkish content to the portal was the insufficiency of the workforce. A group of teachers were given in-service training to meet this 
need within the scope of the Production of Educational Materials through Authoring Software Project (MEB, EĞiTEK, 2008a).

However, this work failed to enrich the Turkish content in the short run. For this reason, in addition to these nationwide campaigns, an attempt was also made to take advantage of foreign education portals such as Skoool.tr, Global Gateway and Think.com by translating them into Turkish. There is a need for still more comprehensive work including the universities and software companies.

Another project whose testing is carried out on the Education Portal is the Information Access Portal Project (MEB EĞiTEK, 2005). The main aim of the Portal was to gather all education stakeholders under the same roof and ensure the continuity of information-sharing among them.

\section{Discussion and Conclusion}

The Turkish education system's becoming acquainted with computers in schools dates back approximately to the $1980 \mathrm{~s}$. During this process, as suggested here, many studies have been carried out with the aim of generalizing the use of the ICT in the field of education and integrating it into the learning-teaching processes and a great number of circulars and regulations regarding the carrying out of the practices at school level have been issued. When the works carried out were evaluated according to their periods, it is necessary to state that more concrete policies and implementation taking all the dimensions of the matter into account began only in the third part of this process. In this respect, the contribution of the eTransformation Turkey Project to the process is important. From the beginning of the integration process until today a great number of projects of foreign and domestic origin have been carried out. The projects carried out in cooperation with the private sector have had important contributions to the project especially regarding the purchasing of hardware.

Although some distance which can be counted as important have been covered until today in the technology integration process in the Turkish Education System, there are a till problems. It is pleasing that the steps taken in the program dimension expressed as one of the preconditions of the integration process in the third period were completed and put into practice. However, within this scope, it is thought-provoking that the part of the Information Technologies course program newly put into practice aiming to have students acquire basic and intermediate level computer literacy skills was removed from the primary education program although it had been in practice for three years. On the other hand, it can be said that we have covered an important distance in the way toward establishing an IT classroom at each school and supplying internet connections to those classrooms. The works carried out in these two dimensions are evaluated among the successful works of the e-Transformation Turkey Project (DPT, 2007). However, unless the problem of crowded classrooms at primary education level is worked out, this problem will continue to affect negatively the efficiency of lessons carried out in IT classrooms as well. Moreover, this problem is one of the factors affecting not only the IT lesson but also the quality of education and teaching at primary education level in a negative way. Besides the slowness of the internet connections in IT classrooms related to infrastructure, it is necessary to mention about deficiencies in peripheral equipments and problems emerging during the arrangements of laboratories due to IT classrooms' being places transformed from old classrooms. Moreover, after the expiring of guarantee, what kind of a policy will be followed in the solution of the maintenance and repair problems of IT classrooms 
has remained uncertain. For this reason, these classrooms face the risk of gradually becoming inactive in the future.

Teachers' inability to integrate the ICTs into learning-teaching processes forms one of the most important obstacles in the use of these technologies at K-12 schools with the aim of teaching. For this reason, it is critical to integrate the ICTs into formal pre-service teacher education. The studies concerning the existing case about ICTs integration processes of teacher training institutions is limited. Thus, the process needs more research that will be handled different view points. It could be useful at this point in accordance with Goktas, Yıldırım, and Yıldırım (2009) and Gulbahar (2008) studies to execute the relevant courses with technology support besides such implementations as proficiency examinations for computer literate courses. Having participated in such a program might encourage teacher candidates to use the technology in their classes. On the other hand, importance should be attached to having teacher candidates acquire knowledge and skills about the use of technology-assisted methods and techniques in such courses as Special Teaching Methods, etc.

Beginning with the introduction of computers into the education system in Turkey, many inservice training programs have been carried out to train teachers serving in the system. The contents of these programs were created within the scope of the integration of the ICT into the learning-teaching processes following the project carried out in collaboration with the Intel firm after 2003. Within this scope, a substantial number of teachers have attended to the trainings given at provincial and district levels until today. Within this scope, studies aiming to investigate into how much teachers reflect the training they have taken into practice are needed.

Another group of teachers serving within the framework of the integration of the ICT into learning-teaching processes are the computer formatter teachers. However, these teachers still have problems about their personal benefits. Furthermore, the authority and responsibilities of these teachers have not been specified clearly yet. For these reasons, these teachers can not be benefited from effectively at school level.

An important element of the integration process is the digital education content, software and teaching materials. One of the important problems emerging with regard to adding Turkish content to the Education Portal established with this aim is the lack of trained staff specialized in this matter. Thoughts regarding the formation of the cadre to give service in this area have not been put into practice yet. On the other hand, the work of producing and developing teaching materials and software is the one entailing specialty, experience and accumulation. However, in Turkey, the people specialized in this matter are not many in number. More comprehensive studies involving universities and software companies in the work of finding a solution to this problem are needed.

Because the Turkish Education System is administered centrally, all investments and pursued made so far today regarding the generalization of the use of ICT in education have been carried out under the auspices of the MNE. The MNE undertakes the guiding role in the implementation of the process by sending the circulars it prepares to schools. The ministry, moreover, demonstrates its expectations and interpretation by preparing various documents regarding the projects under implementation. However, as Özdemir and Kılıç (2007) state, computer coordinators, administrators, and inspectors are not successful in accessing these reports. For this reason, only a few people are aware of the importance that the ministry attaches to the projects. 
What should be done in Turkey for the future is to support the concrete policies and modes of implementation related to the integration of the ICT on a macro level in the third period, considering all dimensions of the matter with those pertinent at the school, at the district and at the province levels on a micro scale. This will ensure the step-up of the process by increasing the use of technology at schools. Schools should share their own experiences, materials and samples concerning the use of ICT in teaching with other schools at first at the district level and then at the province level and should develop new projects by cooperating with them.

When the ICT integration becomes a question at institutional level, we confront two important elements such as technology plan and leadership which become determinants in the success of the process. According to Hoffman (2001), planning underlies institutional change. Barnett (2001) expresses that schools are required to develop an elaborate technology plan to assure the positive effect of technology expenditures on students and staff. Vanderlinde, van Braak, de Windt, Tondeur, Hermans, and Sinnaeve (2008) express that the integration of a shared vision regarding technology use and a participant technology plan for educational purposes seem to have potential benefits for successful technology program implementation. Similarly, other writers (Baylor \& Ritchie, 2002; Bryderup \& Kowalski, 2002) claim that a school-based technology plan is a very important step in the implementation of education technology integration. Hew and Brush (2007) point to the lack of school technology plans among the institutional obstacles regarding the use of technology, and they mention technology integration plans as the second step toward creating success after a shared vision of technology among the strategies to be formed to overcome these obstacles.

In the study by Shoemaker (1997), a positive relationship was found between planning and teachers' use of the Internet. The studies by Cradler and Bridgtorn, (1995) indicated that planning at the school level has a positive effect on teaching and learning and that planning efforts have a great impact on schools (Hoffman, 2001). Tonduer, van Keer, van Braak, and Valcke (2008) found that teachers at schools implementing a detailed technology plan in which aims are emphasized the use of technology regularly in their lessons. Again, Jones (2003) found a strong relationship between school policies and changes in the classroom (Vanderlinde et al., 2008). In the study carried out by Baylor and Ritchie (2002), it was found that schools that have successfully integrated technology into programs are often guided by a comprehensive technology plan. In the study conducted by Mulkeen (2003), the ICT use rates in the lessons at schools in which technology plans are continuously updated ICT were found to be significantly higher than those in others.

For this reason, only a few people are aware of the importance that the ministry attaches to the projects. On the other hand, a legal regulation regarding the development of technology plans at the school level has not been discussed since the beginning of the integration process. For this reason, schools are not obliged to prepare their own technology plans. Thus, the responsibility of the technology integration at the school level is left to school heads; finding resources (though not all of them) and organizing physical, technical and instructional conditions are the responsibility of school administrations. Changing conditions have required school principals to become technology leaders at the same time as well. However, when this condition is taken from the point of Turkey, this matter appears as a problematic area. Within this scope, it is necessary to carry out works in the direction of improving the training and appointment conditions of school principals. 
According to Fishman and Zhang (2003), a technology plan helps practitioners to acquire deep insight into how technology will be adapted to the institution and how it will contribute to the aims of the reform. Again, Lim and Khine (2006) state that a technology integration plan and vision-sharing present school leaders and classroom teachers a consistent communication style related to how to use technology (Hew \& Brush, 2007). The study by Espey (2000) indicates that technology plans and the planning process provide insight into technology integration. Furthermore, a technology plan provides help in sharing the integration vision as well (Espey, 2000). Moreover, sharing the learning and teaching vision in the use of technology performs a supportive function in overcoming leadership obstacles (Tearle, 2004). The findings presented above provide us with some clues regarding the fact that school technology plans give support to school heads during the integration process. Nonetheless, when the matter is viewed from the perspective of Turkey, it is seen that the efforts regarding the preparation of school technology plans in have remained limited to personal work (Gülbahar, 2007; Saban, 2007).

In the course of time, within the scope of the ICT integration at schools, there appears to be a need for specialized cadre, which are called school technologist in the literature, to provide support about the matters of both the preparation of school technology plans and other issues. Within this scope, while dealing with the problems related to the personal rights and powers and responsibilities of computer formatter teachers, this matter should be taken into account. On one side, both the contents of the formal education programs with which these teachers are trained should be revised within the scope of needs and the post-graduate programs to train school technologists should be supported.

\section{References}

Akbaba-Altun, S. (2003). illköğretim okulu müdürlerinin dönüşümcü liderliğe verdikleri önem ve uygulama düzeyleri (Elementary school principals' perceptions and performance about transformational leadership). ilköğretim-online, 2(1), 10-17. Retrieved 18 August 2008 from http://www.Ilkogretim -online.org.tr

Akbaba-Altun, S. (2006). Complexity of integration computer technologies into education in Turkey. Educational Technology \& Society , 9(1), 176-187.

Akbaba-Altun, S. \& Gürer, M. D. (2008). School administrators' perceptions of their roles regarding information technology classrooms. Eurasian Journal of Educational Research, 33, 35-54.

Aktürk, N. (2006). Kurumsal uygulamalar ve e-imza. Retrieved 10 July 2008 from http://www.ueimzas.gazi.edu.tr/pdf/uygulama/06.pdf

Aşkar, P. \& Koçak- Usluel, Y. (2002a). Teknolojinin yayılım sürecinde öğretmenlerin bilgisayarın özelliklerine ilişkin algıları (Perceptions of teachers about the characteristics of computers in the diffusion process of technology). Hacettepe Üniversitesi Eğitim Fakültesi Dergisi, 22, 14-20.

Aşkar, P. \& Koçak- Usluel, Y. (2002b). Öğretmenler ve bilgisayarları kullanmaya ilişkin karar sürecinde bulundukları aşamaları (Teachers and their stages at the tme decision process related to the use of computers). Hacettepe Üniversitesi Eğitim Fakültesi Dergisi, 9, 197202. 
Aşkar, P. \& Koçak- Usluel, Y. (2003). Bilgisayarların benimsenme hızına ilişkin boylamsal bir çalışma: Üç okulun karşılaştııılması (A longitutinual study related to the rate of adoption of computers: Compasion of three schools). Hacettepe Üniversitesi Eğitim Fakültesi Dergisi, 24, 15-25.

Barnett, H. (2001). Successful K-12 technology planning: Ten essential elements. ERIC Document Reproduction Service No (ED 457 858).

Baylor, A.L. \& Ritchie, D. (2002). What factors facilitate teacher skill, teacher morale, and perceived student learning in technology-using classrooms? Computer \& Education, 39, 395-414.

Bayrakçı, M. (2005). Avrupa Birliği ve Türkiye eğitim politikalarında bilgi ve iletişim teknolojileri ve mevcut uygulamalar. Retrieved 27 May 2007 from http://yayim.meb.gov.tr/dergiler/ 167/index3-bayrakci.htm

Bryderup, I.M. \& Kowalski, K. (2002). The role of local authorities in the integration of ICT in learning. Journal of Computer Assisted Learning, 18, 470-479.

Cerit, Y. (2007). Illköğretim okulu müdürlerinin hizmet yönelimli liderlik rollerini gerçekleştirme düzeyleri (Primary school principals' levels of realizing servant leadership roles). Hacettepe Üniversitesi Eğitim Fakültesi, 33, 88-98.

Chang, I.-H., Chin, J. M., \& Hsu, C.-M. (2008).Teacher's perceptions of the dimensions and implimentation of technology leadership of principials in Taiwanese elementary schools. Educational Technology \& Society, 11(4), 229-245.

Çağıltay, K. Çakıroğlu, J. Çağıltay, N. \& Çakıroğlu, E. (2001). Öğretimde bilgisayar kullanımına ilişkin öğretmen görüşleri (Teachers' perspectives about the use of computers in education). Hacettepe Üniversitesi Eğitim Fakültesi Dergisi, 21, 19-28.

Demiraslan, Y. \& Usluel-,Koçak Y. (2005). Bilgi ve iletişim teknolojilerinin öğrenme öğretme sürecine entegrasyonunda öğretmenlerin durumu. The Turkish Online Journal of Educational Technology, 4(1), Article 15. Retrieved 11 October 2008 from http://www. tojet.net/articles/4315

Deryakulu, D. (2005). Bilgisayar öğretmenlerinin tükenmişlik düzeylerinin incelenmesi (The examination of computer teachers' levels of burnout). Eğitim Araştırmaları, 19, 35-53.

Deryakulu, D. \& Olkun, S. (2007). Analysis of computer teacher's online discussion forum messages about their occupational problems. Educational Technology \& Society, 10(4), 131-142.

Devlet Planlama Teşkilatı ([DPT], 2004). e-Dönüşüm Türkiye Projesi Kısa Dönem Eylem Planı 2003- 2004. Retrieved 4 June 42007 from http://ekutup.dpt.gov.tr/plan/aep/edtr/2004.pdf 12

DPT. (2005a). e-Dönüşüm Türkiye Projesi 2003-2004 KDEP uygulama sonuçları ve 2005 Eylem Planı. Retrieved August 31, 2007 from http:// www. bilgitoplumu.gov.tr/yayin/ kdepuygulama sonuclari_2005eylemplani.pdf

DPT. (2005b). Dünya bilgi toplumu zirvesi. Retrieved 29 March 292007 from http://www.bilgitoplumu.gov. tr/dbtz/dbtz/DBTZ-Zirve_Bilgi_Dosyasi-25112005.pdf

DPT. (2006a). Sosyal dönüşüm mevcut durum tespiti nihai rapor. Retrieved 31 August 2007 from http:/ /www. bilgitoplumu.gov.tr/ yayinlar.asp 
DPT.(2006b). Bilgi toplumu stratejisi- 2006-2010. Retrieved 31 August 2007 from http://www.bilgitoplumu.gov.tr/yayinlar.asp

DPT. (2006c). E-Dönüşüm Türkiye Projesi 2005 Eylem Planı sonuç raporu. Retrieved 9 July 2008 from http://www.bilgitoplumu.gov.tr/Documents/1/Icra_Kurulu/060500_IK18.

ToplantisiSonucRaporu.pdf

DPT. (2007). e- Dönüşüm Türkiye Projesi: 2003-2007 arası gelişmeler. Retrieved 9 July 92008 from http://www.bilgitoplumu.gov.tr/IcraKurulu/eD\%F6n\%FC\%FE\%FCm\%20T\%FCrkiye _Ekim\%202007.pdf

DPT. (2008a). 2008 yılı programı tedbirler. Retrieved 31 August 2007 from http://www. ekutup. dpt. gov. tr/ program/2008/tedbir.xls

DPT. (2008b). 2008 yılı kamu bilgi iletişim teknolojileri yatırımları. Retrieved 31 August 2007 from http://www.bilgitoplumu.gov.tr/ yayinlar.asp

DPT. (2008c). T.C. 60. Hükümet Programı Eylem Planı. Retrieved 31 August 312007 from http://www.ekutup.dpt. gov.tr/plan/ep2008pdf.

eAvrupa+ Eylem Planı. (2001). Avrupa'da bilgi toplumunun oluşturulması için ortak girişim. Retrieved 29 March 2007 from http://bilten.metu.edu.tr/eEurope+/Belgeler/ eAvrupa+EylemPlani.pdf

Espey, L. (2000). Technology planning and technology integration: A case study. Retrieved 18 February 2009 from www.editlib.org/p/15535

Eurydice (2007). Türk Eğitim Sisteminin örgütlenmesi 2006 -2007.Eurybase the information databese on education systems in europe. Retrieved 9 June 2008 from http://eacea. ec.europa.eu/ressources/ eurydice/ eurybase/pdf/TR_TR_C4_2.pdf

Fishman, B. J. \& Zhang, B. H. ( 2003). Planning for technology: The link between intentions and use. Educational Technology, 43(4), 14-18.

Goktas, Y., Yıldırım, Z., \& Yıldırım, S. (2008). The keys for ICT integration in K-12 educatıon: Teachers' perceptions and usage. Hacettepe Üniversitesi Eğitim Fakültesi Dergisi, 34, 127-139.

Gulbahar, Y. (2007). Technology planning: A roadmap to successful technology integration in schools. Computers \& Education, 49, 943-956.

Gulbahar, Y. (2008). ICT usage in higher education: A case study on preservice teachers and instructors. The Turkish Online Journal of Educational Technology, 7(1), 32-37.

Hew, K.F. \& Brush, T. (2007). Integrating technology into K-12 teaching and learning: current knowledge gaps and recommendations for future research. Education Technology Research\& Development, 55, 223-252.

Hoffman, E. S. (2001). Technology planning and implementation: A study of effective change efforts in Michigan Public School Distrlct. (Unpublished dissertation). Ypsilanti, Michigan: The Graduate School Eastern Michigan University. Retrieved 1 July 12009 from www.emunix.emich.edu/ehoffman/hoffman01.pdf

Koçak-Usluel, Y. \& Aşkar, P. (2006). Bilgi ve iletişim teknolojilerinin okullarda yayılımı (Diffusion of ICT in schools), retrieved May 5, 2008 from http://www.ebit.hacettepe.edu.tr/ dersnotu/diffusion_of_innovation.pdf

MEB. (1991). Türkiye'de bilgisayar destekli eğitim. Ankara: METARGEM. 
MEB. (1999). 2000 yılında milli eğitim. Ankara: AÇEM ve 4. Akşam Sanat Okulu Matbaası.

MEB. (2002). 2002 yılı başında milli eğitim (MEB Istatistik 2002). Retrieved 5 July 2007 from http://www.meb. gov.tr/Stats/Apk2002/502.htm

MEB. (2003). Milli Eğitim Bakanlığı bilgi iletişim teknolojileri politika taslak dökümanından alıntılar. Retrieved 9 July 2008 from http://bilisimsurasi.org.tr/listeler/tbs-egitim/ 2003/Dec/att-0067/01-BIT_Politika.doc

MEB. (2004). Proje ön değerlendirme dökümanı. Retrieved 10 June 2008 from http://www. meb.gov.tr/duyurular/Projeler/TEPIIFazOnHazDokuman2004/TEPPadFazIITurkce.pdf

MEB. (2005). Avrupa birliği kredisi ile yürütülmek üzere hazırlanan projeler; Temel eğitimin desteklenmesi projesi. Retrieved 10 June 2008 from http://tedp.meb.gov.tr/main. php?ID=10

MEB. (2006a). Milli Eğitim Bakanlığına bağlı örgün ve yaygın eğitim kurumlarında bilgisayar laboratuarlarının düzenlenmesi ve işletilmesi ile bilgisayar ve bilgisayar koordinatör öğretmenlerinin görevleri hakkında yönerge [Mevzuat Bankası]. Retrieved 18 May 2006 from http://mevzuat.meb.gov.tr/html/2378_1.html

MEB. (2006b). Milli Eğitim Bakanlığı Strateji Geliştirme Başkanlığı 2006 yılı faaliyet raporu. Retrieved 10 September 2007 from http://sgb.meb.gov.tr/ickontrol/MEB\%20FAAL\% C4\% BOYET\%20RAPORU\%202006.pdf

MEB. (2007a). Temel eğitime destek programı (TEDP) tartışma raporu "strateji raporu. Retrieved 10 September 2007 from http://tedp.meb.gov.tr/main.php?ID=10 Strateji Raporu.

MEB. (2007b). MEB internete erişim projesi. Retrieved 10 August 2007 from http://www. meb.gov.tr/ ADSL/ adsl_index.html

MEB. (2008). Bilgisayarlı eğitime destek kampanyası başladı. Retrieved 9 July 2008 from http://www.meb.gov. tr/haberler/haberayrinti.asp?ID=918

MEB EĞITEK. (2001).07.06.2001 tarih ve 5985 sayılı "Bilgi Teknolojilerinin Kullanımı (Genelge No: 2001/53)" konulu genelge.

MEB EĞiTEK. (2002). Çağı yakalama 2000 projesi, Milli Eğitim Bakanlığı, e- Dönüşüm. Retrieved 5 July 2007 from http://www.ankarakolejias.com.tr/milliegitim.htm

MEB EĞiTEK. (2003a). Eğitim teknolojileri etkinlikler 2002. Retrieved 5 July 2007 from http://egitek.meb.gov.tr /Egitek/Kitaplar/Etkinlikler2001/Etkinlikler2002.html

MEB EĞITEK. (2005). 05.12.2005 tarih ve 17142 sayılı "Bilgiye Erişim Portalı" konulu genelge.

MEB EĞiTEK. (2007a). Bilişim teknolojileri formatör öğretmen eğitim programı. Retrieved 2 February 2008 from http://bitefo.meb.gov.tr/24_bitefo.pdf.

MEB EĞiTEK. (2007c). 04.07.2007 tarih ve 12089 sayılı "Bilişim Teknolojisi Formatör Öretmen Görevlendirmesi" konulu genelge.

MEB EĞiTEK. (2008a). Eğitim teknolojileri genel müdürlüğü. Retrieved 10 June 2008 from http://egitek .meb .gov.tr/Egitek/Birimlerimiz/Birimlerimiz.html.

MEB EĞiTEK. (2008b). Eğitim Teknolojileri Genel Müdürlüğü tarafından yürütülen projeler.(The projects carried out by Educatioanal Technologies General Directorate). Retrieved 4 June 2008 from http://egitek. meb. gov. tr/KapakLink/ Projeler/ YurutulenProjeler.html 
MEB EĞiTEK. (2009). 19.08.2009 tarih ve 16654 sayılı "CS4 Yazarlık Yazılımları" konulu genelge.

MEB TTKB. (2007). Talim Terbiye Kurulu program geliştirme çalışmaları. Retrieved 27 February 2007 from http://ttkb.meb.gov.tr/programlar/prog giris/prg giris.pdf

Mulkeen, A. (2003). What can policy makers do to encourage integration of information and communications technology? Evidence from the Irish school system. Technology, Pedagogy and Education, 12(2), 277-293.

Orhan, F. \& Akkoyunlu, B. (2003). Eğitici bilgisayar formatör (master) öğretmenlerin profilleri ve uygulamada karşılaştıkları güçlüklere ilişkin görüşleri (Profiles and opinions of the computer formative teachers' on the difficultiesthey have faced during the applications). Hacettepe Üniversitesi Eğitim Fakültesi Dergisi, 24, 90-100.

Özdemir, S. \& Kılıç, E. (2007). Integrating information and communication Technologies in the Turkish primary school system. British Journal of Educational Technology,38(5), 907-916.

Saban, A. (2007). Seçmeci okul teknoloji planlama modeli ve Özel Konya Esentepe İlköğretim Okulu teknoloji profili (Eclectic school technology planning model and private Konya Esentepe elemantary school's technology profile). Sosyal Bilimler Enstitüsü Dergisi, 22(1), 23-43.

Şimşek, H. (2009, Nisan). Türkiye'de okul liderliği. Okul Liderliğinin Geliştirilmesi Konferansı'nda yapılan sunum. Ankara: MEB, DiGM. Retrieved 14 September 2009 from http://digm. meb.gov.tr/... /7.\%20Prof.\%20Dr.\%20 Hasan\%20SIMSEK\%2Sunusu.ppt

Şimşek, N. (1998). Öğretim amaçlı bilgisayar yazılımlarının değerlendirilmesi-Kavramlar, teknikler, araçlar ve uygulama. Ankara: Siyasal Kitabevi.

Taslak Rapor, (10-11 Mayıs, 2004). Türkiye 2. Bilişim Şûrası. Retrieved 11 September 2007 from http://www. bilisimsurasi.org.tr/raporlar/TaslakRapor.pdf

Tearle, P. (2004). A theoretical and instrumental framework for implemanting change in ICT in education. Cambridge Journal of Education, 34(3), 331-351.

Thorburn, D. (2004). Technology integration and educational change : Is it possible?. Retrieved 4 February 2009 from http://www.usask.ca/ education/couswork/802papers/ thourburn/index.htm

Tondeur, J., van Keer, H., van Braak, J., \& Valcke, M. (2008). ICT integration in the classroom: Challenging the potential of a school policy. Computer \& Education, 51, 212-223.

Usluel-Koçak, Y., Mumcu-Kuşkaya, F., \& Demiraslan, Y. (2007). Öğrenme-öğretme sürecinde bilgi ve iletişim teknolojileri: Öğretmenlerin entegrasyon süreci ve engelleriyle ilgili görüşleri (ICT in the learning-teaching process: Teachers' views on the integration and obstacles). Hacettepe Üniversitesi Eğitim Fakültesi Dergisi, 32, 164-178.

Uyanıker, L. (2007). Altyapı MEB'den içerik öğretmenden. BT Haber 13-19 Ağustos, s.3.

Vanderlinde, R., van Braak, J. De Windt, V. Tondeur, J. Hermans, R., \& Sinnaeve, I. (2008). ICT International technology curriculum and planning for technology in schools: The Flemish case. TechTrends, 52(2), 23-26.

YÖK. (2007). Öğretmen yetiştirme ve eğitim fakülteleri (1982- 2007). Ankara: YÖK.

Yucel, C., Acun, I., Tarman, B., \& Mete, T. (2010). A model to explore Turkish teachers' ICT integration stages. The Turkish Online Journal of Educational Technology, 9(4), 1-9. 
Correspondence: Nuray Parlak Yilmaz, Assistant Professor, Department of Computer Education and Instructional Technologies, Faculty of Education, Uludag University, Gorukle, Bursa, Turkey 